\title{
FAKTOR DUKUNGAN ORANG TUA DENGAN STRATEGI COPING REMAJA MENGHADAPI BULLYING DI SMP MALANG
}

\author{
Parents Support Factors With Adolescent Coping Strategies Facing Bullying \\ In Malang Junior High School
}

Shanty Natalia, ${ }^{1}$ Ana Dwi Lestari ${ }^{2}$,

${ }^{1}$ Institut Ilmu Kesehatan STRADA Indonesia

Riwayat artikel

Diajukan: Agustus 2021

Diterima: September 2021.

\section{PenulisKorespondensi: \\ - Shanti Natalia \\ - Institut Ilmu \\ Kesehatan STRADA \\ Indonesia \\ - syifasha@gmail.com}

\section{Kata Kunci:}

Dukungan Orangtua,

Strategi Coping, Bullying

\section{Abstrak}

Permasalahan yang sering dihadapi remaja dimana terjadinya buliying di mana-mana dan pada semua umur dan jenis kelamin yang menjadi korban umumnya adalah anak yang lemah, pemalu, pendiam dan spesial (cacat, tertutup, pandai, cantik, atau punya ciri tubuh tertentu), yang dapat menjadi bahan ejekan. Tujuan dari penulisan penelitian ini adalah untuk mengetahui hubungan dukungan orang tua dengan strategi coping remaja menghadapi bullying di SMP Malang.

Penelitian ini menggunakan desain penelitian ini adalah deskriptif korelatif yaitu penelitian untuk menelaah hubungan antara dua variabel pada suatu situasi atau sekelompok objek dengan pendekatan cross sectional. Penelitian dilaksanakan di SMP Malang. Teknik sampling mengunakan random sampling 74 siswa. Hasil penelitian menunjukan bahwa Distribusi responden pada dukungan cukup sebanyak $27(36,5 \%)$, Distribusi responden pada startegi coping cukup sebanyak 32 (36,5\%). Hasil analisa Data kemudian diuji dengan menggunakan uji statistik Spearman rank. Hasil Spearman rank didapatkan p $(0,000)<0,05$ maka H1 diterima dan ditolak H0. Berdasarkan hasil penelitian disimpulkan bahwa ada hubungan hubungan dukungan orang tua dengan strategi coping remaja menghadapi bullying di malang. Disarankan agar orang tua selalu mensuport anaknya hal ini dapat meningkatkan stategii coping remaja.

\section{Abstract}

Problems that are often faced by adolescents where the occurrence of buliying everywhere and at all ages and genders of victims are generally weak, shy, quiet and special children (disabled, closed, clever, beautiful, or have certain body traits), which can be a mockery. The purpose of writing this study is to find out the relationship of parental support with bullying coping strategies in Junior High School of Malang. This study using the design of this study is descriptive correlative i.e. research to study the relationship between two variables in a situation or a group of objects with a cross sectional approach. The research was conducted in malang. Sampling techniques usingrandom sampling 74 students. 
The results showed that the distribution of respondents on support is enough asmuch as 27 (36.5\%), Distribution of respondents at startegi coping enough as much as 32(36,5\%). The data analysis results were then tested using Spearman rank statistical tests. Spearman rank result obtained $p(0.000)<0.05$ then $\mathrm{H} 1$ received and rejected $\mathrm{HO}$.

Based on the results of the study concluded that there is a relationship of parental support with bullying coping strategies in Junior High School of Malang. It is recommended that parents always support their children this can increase the stategi coping of adolescents. 


\section{Pendahuluan}

Perilaku adalah kegiatan manusia atau mahluk hidup lain yang dapat dilihat secara langsung pada waktu tertentu disuatu waktu tertentu. Salah satu jenis dari perilaku adalah perilaku bullying, seperti menggertak atau mengganggu. Hal ini merupakan bagian dari perilaku agresif anak secara berulang terhadap temannya atau sesama siswa lainnya yang menyebabkan adanya korban, hal ini dilakukan secara tertutup dalam sebuah kelompok kecil yang terbatas, dan seringkali tindakan itu dilakukan sejak mereka masih belia. Karena jenis tindakannya yang cenderung bersifat rahasia, maka komunitas di sekitarnya tidak mengetahui peristiwa itu (Astuti, 2017). Perilaku buly merupakan tingkah laku yang kompleks. Anak- anak tidak dilahirkan untuk menjadi seorang pembuli. Tingkah laku buly juga tidak diajarkan secara langsung kepada anakanak. Terdapat berbagai faktor yang mempengaruhi seorang anak berkembang menjadi pembuli. Faktor-faktor tersebut termasuk faktor biologi dan temperamen, pengaruh keluarga, teman, dan lingkungan. Penelitian membuktikan bahwa gabungan faktor individu, sosial, resiko lingkungan, dan perlindungan berinteraksi dalam menentukan etiologi perilaku buli (Yusuf, 2012).

Bullying terjadi ketika satu atau lebih siswa berusaha untuk memiliki kekuasaan atas siswa lain melalui penggunaan verbal, fisik atau emosional pelecehan, intimidasi atau bahkan isolasi. Intimidasi adalah, perilaku agresif terus menerus disengaja terhadap orang, korban, yang tidak bisa membela diri, dan ini biasanya melibatkan ketidakseimbangan kekuasaan antara agresor dan korban. Setiap perilaku pameran orang, dengan maksud untuk menyakiti orang lain secara fisik atau psikologis, tanpa penyebab, dianggap suatu tindakan bullying (Nwokolo $\mathrm{C}$ dan Efobi A, 2014). Bullying terjadi di mana- mana dan pada semua umur dan jenis kelamin yang menjadi korban umumnya adalah anak yang lemah, pemalu, pendiam dan spesial (cacat, tertutup, pandai, cantik, atau punya ciri tubuh tertentu), yang dapat menjadi bahan ejekan (Astuti, 2017). Perilaku bullying dapat menyebabkan dampak serius, seperti luka batin bagi korbannya dan bahkan ada korban yang bunuh diri (Salmi, 2018). Jumlah kasus bullying yang terjadi didunia terbilang tinggi. Berdasarkan data yang dihimpun oleh Unesco, diperkirakan sekitar 246 juta anak dan remaja di dunia mengalami berbagai bentuk kekerasan dan bullying di sekolah setiap tahunnya (UNESCO, 2017). Di Indonesia, berdasarkan data publikasi yang dihimpun dari bank data Komisi Perlindungan Anak Indonesia (KPAI), jumlah kasus bullying pada anak dan remaja periode tahun 2011-2016 mencapai 1.174 kasus (Komisi Perlindungan Anak Indonesia, 2016. Komisioner KPAI Bidang Pendidikan Retno Listyarti menyebutkan jika kasus cyber bully di tahun 2016-2020 yang melapor ke KPAI mengalami peningkatan. Hal ini harus menjadi perhatian khusus mengingat peningkatan kasus bullying yang tinggi, yakni sekitar 41\% (Vina Fadhrotul Mukaromah, 2020). Data kabupaten malang di dapatkan pada tahun 2020 dari data KPAI angka kejadian perlindungan anak kasus bullying yang terlaporkan sejumlah 450 kasus(KPAI, 2020)

Pada studi pendahuluan di SMP Malang bulam maret 2021 didapatkan data dari 10 anak remaja, 4 tidak pernah mengalami bullying, 2 remaja diantaranya pernah mengalami bulliying secara verbal berupa ejekan kepada teman-temannya sampai teman yang diejek menangis, sindir sindiran, 2 remaja pernah mengalami bulliying berupa di cubit dan 2 remaja pernah mengalami cyber bulliying di salah satu media sosial, hal ini berdampak pada kehidupan individu remaja maupun akademik serta 
perilaku sosial diantaranya menjadi tidak percaya diri, merasa tidak nyaman dan merasa terisolasi. Dan dari 10 orang tersebut 7 anak belum tahu bagaimana cara menghadapi atau mengatasi bullying.

Beberapa bentuk bullying yang sering terjadi yaitu: bullying fisik berupa kontak fisik antara pelaku dan penyintas bullying, bullying verbal berupa ucapan atau kata-kata yang ditujukan kepada penyintas bullying, dan bullying psikologis berupa tindakan tersirat yang menyerang psikologis penyintas bullying (Amini, 2008). Senada dengan pendapat tersebut, bentuk bullying yang sering terjadi di kalangan remaja meliputi: bullying verbal seperti ucapan yang tidak pantas, pemberian julukan, jelek, celaan, dan ancaman secara verbal; bullying fisik seperti memukul, mencekik, menendang, meludahi, merusak dan menghancurkan barang; serta bullying psikologis seperti pengucilan secara relasional, lirikan mata, helaan nafas, tawa mengejek serta bahasa tubuh yang kasar (Aini, 2016) . Korban bullying sebenarnya sangat mengharapkan dukungan keluarga dan lingkungannya untuk menyelesaikan masalah yang dihadapi (Putra dan Ariana, 2016). Dukungan orangtua adalah dukungan yang diberikan oleh orangtua kepada anaknya baik secara emosional penghargaan, instrumental, informasi ataupun kelompok. Melalui dukungan orangtua yang baik maka dapat membantu tumbuhnya kemampuan penyesuaian dirpada remaja (Sochib, 2008). Peran orang tua dan pendidik di sekolah sama pentingnya dalam menghadapi tindakan bullying, orang tua dan guru harus bekerjasama untuk membantu baik bagi para korban maupun pelaku bullying untuk menciptakan lingkungan yang positif antar siswa satu dengan yang lain di sekolah (Ifa, Nurjanah, Suryaningsih, 2017).

$$
\text { Penelitian terkait tentang }
$$

dukungan orang tua yaitu penelitian tentang hubungan dukungan orang tua dengan konsep diri pada remaja di
SMAN 1 Manado oleh Durado, Tololiu, Pangeman pada tahun (2013) terhadap 118 responden. Hasil analisis menunjukkan nilai $\mathrm{p}=0,026$ yang menyatakan bahwa ada hubungan yang signifikan antara dukungan orangtua terhadap konsep diri remaja dimana semakin baik dukungan orangtua maka konsep diri remaja akan semakin positif. Pada penelitian ini menyatakan bahwa keluarga sebagai kelompok sosial terkecil dalam masyarakat, mempunyai peran penting dalam memberikan dukungan, curahan kasih sayang, arahan, dan pengawasan kepada anak agar ia tumbuh percaya diri.

Dukungan orang tua merupakan sistem dukungan sosial yang terpenting dimasa remaja dibandingkan dengan sistem dukungan sosial lainnya. Dukungan orang tua dapat mempengaruhi jati diri seorang anak yang dapat meningkatkan kemampuannya dalam beradaptasi terhadap suatu masalah yang dapat meningkatkan mekanisme koping pada remaja. Dalam hal ini tidak hanya dukungan saja tetapi korban bullying memerlukan suatu kemampuan atau usaha dalam menyelesaikan permasalahannya. Menurut (Annisya, 2020) perlu adanya strategi individu untuk melakukan adaptasi dari berbagai tekanan dan perubahan pada konflik yang dihadapi. Adaptasi yang dilakukan setiap individu satu dengan yang lain beraneka ragam ada berbagai cara yang dapat dilakukan untuk mengatasi suatu permasalahan. Strategi coping merupakan salah satu cara atau sebagai fokus utama yang dapat dilakukan oleh korban bullying untuk mengurangi atau menghilangkan kondisi tertekan akibat dampak bullying yang diterima.

Menurut (utomo, 2016) strategi coping adalah usaha individu untuk mengelola stress dengan cara tertentu. Strategi coping sebenarnya berasal dari kata coping yang artinya usaha yang dilakukan individu untuk mengatasi tuntutan internal dan eksternal sebagai 
sesuatu yang membebani dan menganggu kelangsungan hidup. Hasil penelitian menunjukkan bahwa minoritas individu dengan coping rendah ketika menghadapi masalah bullying dikarenakan kemampuan individu untuk menghadapi stress dan tekanan yang dialaminya tidak efektif dan kurangnya kemampuan untuk mengatasi masalah sehingga berpengaruh pada kepribadian individu. Untuk mengatasi masalah bullying kita sebagai tenaga yang bergerak dibidang kesehatan dan sebagai orang yang berpendidikan maka diharapkan kita bisa membantu mengingatkan orangtua sebagai lingkungan terdekat remaja ataupun guru sebagai pendidik remaja untuk memberikan dukungan dan pengarahan dalam menghadapi masalah bullying tersebut sehingga coping remaja meningkat. Dalam mengatasi masalah yang muncul akibat bullying dan bullying merupakan masalah kesehatan public perlu mendapatkan perhatian sehingga remaja membutuhkan dukungan orang tua untuk meningkatkan resiliensinya yang akan berdampak terhadap fondasi karakter remaja dan masa depannya yang lebih berkualitas (Zainal, 2011).

\section{Metodologi}

Desain penelitian ini adalah Correlation Research Penelitian ini dilakukan untuk melihat hubungan diantara dua variabel, dengan pendekatan cross sectional merupakan suatu penelitian yang mempelajari korelasi antara paparan atau faktor risiko (independen) dengan akibat atau efek (dependen), dengan pengumpulan data dilakukan bersamaan secara serentak dalam satu waktu antara faktor risiko dengan efeknya (point time approach), artinya semua variabel baik variabel independen maupun variabel dependen diobservasi pada waktu yang sama. Sample pada penelitian ini berjumlah 74 responden. Variabel independent dukungan orang tua dan variabel dependent strategi coping. Instrument pada penelitian ini mengunakan lembar kuisioner dukungan orangtua dan kuisioner strategi coping. Analisis pada penelitian ini mengunakan uji spearman Derajat kemaknaan ditentukan $\alpha=0,05$

\section{Hasil dan Pembahasan}

Dari hasil penelitian yang dilakukan di Malang didapatkan data dari 74 responden Distribusi frekuensi responden berdasarkan dukungan orang tua

\begin{tabular}{|c|c|c|}
\hline Dukungan orang tua & $\begin{array}{l}\text { Freku } \\
\text { ensi }\end{array}$ & $\begin{array}{l}\text { Prese } \\
\text { ntase }\end{array}$ \\
\hline Dukungan rendah & 15 & 20,3 \\
\hline Dukungan cukup & 27 & 36,5 \\
\hline Dukungan tinggi & 20 & 27,0 \\
\hline $\begin{array}{l}\text { Dukungan } \\
\text { tinggi }\end{array}$ & 12 & 16,2 \\
\hline Total & 74 & 100 \\
\hline \multicolumn{3}{|c|}{$\begin{array}{l}\text { Sumber data : Data Primer juni } 2021 \\
\text { Dapat dilihat dari Tabel } 4.4 \\
\text { bahwa distribusi responden }\end{array}$} \\
\hline \multicolumn{3}{|c|}{$\begin{array}{l}\text { Distribusi frekuensi responden berdasarkan } \\
\text { strategi coping }\end{array}$} \\
\hline trategi koping & $\begin{array}{l}\text { Frekuen } \\
\text { si }\end{array}$ & Presentase \\
\hline trategi Koping Rendah & 10 & 13,5 \\
\hline trategi Koping Cukup & 32 & 43,2 \\
\hline trategi Koping Tinggi & 20 & 27,0 \\
\hline $\begin{array}{lll}\text { trategi } & \text { Koping } & \text { Sangat } \\
\text { inggi } & & \\
\end{array}$ & 12 & 16,2 \\
\hline otal & 74 & 100 \\
\hline
\end{tabular}

Sumber data : Data Primer juni 2021

Dapat dilihat dari Tabel 4.5 bahwa distribusi responden pada startegi coping cukup sebanyak $32(43,2 \%)$ 
Hasil uji korelasi Spearman

\begin{tabular}{lll}
\hline & & Strategi coping \\
\hline $\begin{array}{l}\text { Dukungan } \\
\text { orang tua }\end{array}$ & $r$ &, $493^{* *}$ \\
& $p$ &, 000 \\
& $\mathrm{n}$ & 74 \\
\hline Total & 74 & $100 \%$ \\
\hline
\end{tabular}

Sumber data : Data Primer juni 2021

Dapat dilihat dari Tabel 4.7 Dari

hasil analisis berdasarkan hasil output diketahui nilai Asymp.Sig(2-tailed) pada uji Spearman adalah sebesar 0,000, karena hasil $\mathrm{P}$ Value $<0,05$ maka $\mathrm{H} 0$ ditolak dan $\mathrm{H} 1$ diterima berati ada dukungan orang tua dengan strategi coping remaja menghadapi bullying di Malang, dimana hasil analisis arak korelasi termasuk korelasi positif, $493^{* *}$ artinya semakin tinggi dukungan semakin tinggi strategi koping, sedangkan kekuatan korelasi dengan hasil $r=, 493^{* *}$ menurut sugiono (2017) berada dalam korelasi kategori sedang.

\section{Menganalisis Dukungan Orang Tua Menghadapi Bullying di SMP Malang.}

\footnotetext{
Dapat dilihat dari Tabel 4.4 bahwa distribusi responden pada dukungan orang tua cukup sebanyak 27 $(36,5 \%)$. Hal ini sesuai dengan penelitian Nobelina Adicondro \& Alfi Purnamasari (2011) dimana pada penelitian tersebut Mayoritas responden memiliki dukungan orang tua cukup tinggi dengan responden berjumlah 62 responden dan didapatkan hasil yang memiliki dukungan keluarga tinggi sebanyak 29 (46,77\%), (Rahmawati, 2011), menyebutkan bahwa hubungan dekat seperti anggota keluarga dan teman-teman dekat lebih memugkinkan untuk memberikan dukungan. Hal ini dikarenakan ada.nya tanggung jawab untuk mendukung, perhatian yang lebih besar dan adanya harapan timbal balik. Dengan demikian dapat dikatakan bahwa keiintiman hubungan merupakan salah satu faktor
}

yang. berpengaruh terhadap adanya dukungan kieluiarga inti. Keluarga yang berfungsi memiliki kompetensi yang baik pada pengasuhan remaja (Angley, Divney, Magriples, \& Kershaw, 2014) Hal ini juga sejalan dengan hasil penelitian Anita Sari (2013) yang berjudul "Deskripsi Tentang Bullying pada Remaja di SMP Setia budhi semarang berdasarkan Dukungan Keluarga", dimana menunjukan anak yang mendapatkan dukungan keluarga memiliki tingkat kecenderungan bullying lebih rendah dibandingakan dengan anak yang tidak mendapatkan dukungan orang tua. Anak yang mendapatkan dukungan keluarga merupakan anak yang dib|ina dan tumbuh kemba|ng denga|n kasih sayang. sebagaimana dalam keluarga yang kurang harmonis dan jarang terjadi pertengkaran antara kedua orang tua serta kepada anakanaknya, akan menjadikan anak terbiasa dengan tindakan-tindakan yang dilakukan oleh orang tuanya kepada teman temannya. Hal ini seperti yang diungkapkan oleh Novianti (2008 dalam Anita Sari. 2013). rumah tangga yang di penuhi kekerasan atau bullying yang dilaku| kan antara orang tua atau pada anak-anak|nya jelas berdamp|ak pada anak. anak ketika beranjak remaja, mereka belajar bahwa bullying suatu bagian dari dirinya sehingga hal yang wajar bagi dirinya melakukan bullying pada orang lain. (Anita Sari. 2013). Orang tua menjadi salah satu prediktor anak terlibat dala|m tind|akan bullying (Kokkinos, 2013). Hal serupa juga terdapat pada hasil penelitian yang dilakukan oleh Gao et al., (2013) yang menyatakan bahwa fungsionalitas keluarga memiliki hubungan dengan perilaku menyimpang. Kurangnya keharmon|isan anggota kelua|rga dan perhatian dari orang tua menjadi prediktor perilaku bullying, begitu juga sebalikny|a. Keluarga yang berf|ungsi adalah keluarga yang mampu untuk memberikan kontrol sos|ial (Gao et al., 
2013). anak yang memiliki masalah yang dihadapi dalam keluarga lebih cenderung asal masalah berasal dari sang ayah. Bagaimana kekerasan keluarga biasa di akibatkan oleh seorang ayah menyebabkan kekerasan dalam rumah tangga yang berimbas kepada anak yang menimbulkan trauma.sehingga berisiko bahwa anak tersebut ikut terlibat perundungan di sekolah (Else E. Vries 2017)

Keluarga sangat mempengaruhi anak dalam bertingkah laku di luar lingkungan keluarga. Latar belakang para pelaku bullying memiliki kekhasan, banyak di antara mereka orangtuanya tidak memberikan panduan atau bimbingan yang cukup mengenaiperilaku positif. Biasanya pelaku melakukan bullying untuk mendapatkan hal yang tidak dipenuhi oleh keluarga komunikasi yang baik (Sudarsono dalam Suryani dan Widyasih, 2010).

Menurut asumsi peneliti dukungan orang tua diharapkan dapat semaksimal mungkin diberikan pada usia remaja khususnya usia SMP dimana pada usia ini remaja rasa ingin tahu yang besar, sehingga membutuhkan pengarahan dukungan dan kasih sayang dari orang tua. Dalam menyikapi kasus bullying yang terjadi para remaja membutuhkan support orang tua untuk meningkatkan rasa percaya diri, dalam menghadapi masalah dan membuthkan arahan yang positif untuk permasalahan yang dialami, dalam hal ini keluarga adalah pilar utama untuk menampung keluh kesah sang anak.

\section{Menganalisis Strategi Coping Remaja Menghadapi Bullying di SMP Malang.}

Dapat dilihat dari Tabel 4.5 bahwa distribusi responden pada startegi coping cukup sebanyak $32(43,2 \%)$ Hal ini sejalan dengan Stenhald dan Dolbler (dalam Pratiwi \& Hirmaningsih 2016) menemukan hasil penelitian bahwa semakin tinggi kemampuan koping maka semakin baik dalam menghadapai tekanan bulliying. Hal ini selaras dengan penelitian Yuliandari (2017) Dari hasil penelitian yang dilakukan dapat diketahui bahwa reaksi setiap orang akan berbeda dalam menghadapi tekanan bulliying.

Bullying di sekolah merupakan fenomena yang terjadi pada seorang peserta didik yang merasa bahwa dirinya diperlakukan secara tidak sewajarnya atau adanya diskriminasi terhadap dirinya. Permasalahn Bullying yang terjadi di sekolah ini biasanya akan mengakibatkan dampak yang tidak baik, bahkan dapat menggangu kondisi kejiawaan siswa itu sendiri dari kekerasan atau diskriminasi sepynting dialanuiạngtrategi copirang-łodragiyang diingin upaya yang dilakukan oleh individu untuk mengelola tuntutan eksternal dan internal yang dihasilkan dari sumber stress menurut Gowan et al,dalam (utomo,2016). Melalui kemampuan memecahkan masalah yang didasari oleh kreativitas akan mengarahkan individu untuk dapat mencari informasi-informasi yang relevan guna membantunya menganalisa situasi permasalahan supaya mampu mengidentifikasi masalahnya dan menghasilkan alternatif tindakan serta membuat pertimbangan alternatif kemudian melaksanakan tindakan secara tepat. Sedangkan, tuntutan eksternal merupakan keterampilan memecahkan masalah yang didukung kreativitas akan memudahkan individu dalam menghasilkan ide-ide alternatif tindakan, lebih flexibel dalam melakukan analisa situasi permasalahan serta lebih mudah dalam menguraikan idenya menjadi langkah-langkah tindakan yang tepat.

Strategi koping yang diterapkan para individu dalam menghadapi stres yang ditimbulkan akibat cyberbullying tentunya dapat berbeda satu sama lain. Penelitian yang dilakukan oleh 
Machackova, et al. (dalam Putra dan Ariana, 2016), menyebutkan bahwa remaja mempunyai strategi koping tertentu yang dapat mengakibatkan dua hal, antara lain memperlambat emosi negatif dan atau memberhentikan agresi dunia maya yang mereka terima. Berdasarkan penelitian sebelumnya mengenai ketiga bentuk strategi koping tersebut ditemukan bahwa gender seseorang tidaklah berpengaruh dalam memilih ketiga jenis strategi coping tersebut. Presepsi seseorang dalam menyelesaikan masalah akan lebih berpengaruh dalam pemilihan strategi copingnya.

Asumsi peneliti anak usia remaja banyak sekali permasalahan yang timbul pada fase sosial terutama pada pertemanan, perselisihan serta rasa ingin diakui dalam suatu komunitas membuat mereka melakukan perilaku bullying, hal ini dikarenakan ingin mendapatkan pengakuan pada suatu komunitas, pada keadaan ini pastilah ada korban korban bullying, seorang siswa haruslah dibekali strategi koping yang sesuai dengan karakteristik dirinya, banyak sekali metode strategi koping yand dapat di pilih untuk mengatasi atau menghadapi perilaku bullying. Mengingat bulling dapat terjadi kapan saja, dimana saja dan kepada siapa saja. Hal ini bertujuan untuk meminimalkan dapak negatif, serta stategi koping yang bagus pada fase remaja ini agar motivasi belajar serta prestasi belajar siswa tidak menurun hanya karena kasus bullying.

\section{Menganalisis Hubungan Dukungan Orang Tua Dengan Strategi Coping Remaja Menghadapi Bullying di SMP Malang.}

Dilihat dari tabel 4.6 hasil tabulasi silang antara dukungan keluarga cuku, stategi koping cukup (20,3\%), dan dapat dilihat dari Tabel 4.7 Dari hasil analisis berdasarkan hasil output diketahui nilai
Asymp.Sig(2-tailed) pada uji Spearman adalah sebesar 0,000, karena hasil $\mathrm{P}$ Value <0,05 maka H0 ditolak dan H1 diterima berati ada dukungan orang tua dengan strategi coping remaja menghadapi bullying di Malang, dimana hasil analisis arah korelasi termasuk korelasi positif ,493 ${ }^{* *}$ artinya semakin tinggi dukungan semakin tinggi strategi koping , sedangkan kekuatan korelasi dengan hasil $r=, 493^{* *}$ menurut sugiono (2017) berada dalam korelasi kategori sedang.

Hal ini sejalan dengan penelitian Astuti, (2015) Hasil penelitian menunjukkan bahwa siswa kelas XII SMK Negeri 3 Yogyakarta memiliki tingkat dukungan sosial orang tua pada kategori sedang sebanyak 158 siswa $(69,6 \%)$ dan tingkat strategi coping berfokus masalah pada kategori sedang sebanyak 176 siswa (77,5\%). Menurut Sartika dan Kurniawati (2016) dukungan orang tua kesadaran akan tanggung jawab mendidik dan membina anak secara teru menerus dengan memberikan bantuan oleh orang tua terhadap anak untuk memenuhi kebutuhan dasar anak dalam wujud pemberian perhatian, perasaan aman dan nyaman, serta rasa kasih sayang. Dalam Risnawati (2020) perlu adanya strategi individu untuk melakukan adaptasi dari berbagai tekanan dan perubahan pada konflik yang dihadapi. Namun cara adaptasi yang dilakukan setiap individu beraneka ragam. . Strategi coping merupakan salah satu cara atau sebagai fokus utama yang dapat dilakukan oleh korban bullying untuk mengurangi atau menghilangkan kondisi tertekan akibat dampak bullying yang diterima. Menurut Utomo (2016) strategi coping adalah usaha individu untuk mengelolastress dengan cara tertentu.

Menurut Gowan et al,dalam (utomo,2016) Bullying yang terjadi di sekolah akan mengakibatkan dampak yang tidak baik. Dalam (Angelia,2021) Seseorang yang pernah menjadi korban bullying akan berdampak pada kondisi 
fisik dan psikologis. Menurut Utomo (2016) bullying memiliki pengaruh dampak jangka panjang dan jangka pendek, dalam jangka pendek korban bullying dapat mengalami penindasan, menurunnya minat belajar dan bersosialisasi sedangakan untuk jangka panjang korban bullying dapat mengalami kecemasan dan kesulitan dalam beradaptasi dengan lingkungan baru. Dampak bullying baik dari sisi korban dan pelaku sama-sama akan mengalami masalah kesehatan psikologis yang berupa bagi pelaku bullying timbul perasaan bersalah karena melanggar norma sedangkan bagi korban timbul rasa trauma, teori dari Putra dan Ariana (2016) korban bullying sebenarnya sangat mengharapkan dukungan keluarga dan lingkungannya. Sedangkan menurut Puspita dan Kustanti (2018) kebanyakan remaja sering menghabiskan waktu dengan teman- temannya dibadingkan dengan keluarganya sehingga mereka merasa nyaman apabila bercerita dengan teman-temanya daripada keluarganya. Walaupun begitu dukungan dari berbagai pihak dari keluarga, teman, maupun sosial sama pentingnya bagi korban bullying untuk berbagi keluh kesah. Dalam hal ini tidak hanya dukungan saja tetapi korban bullying memerlukan suatu kemampuan atau usaha dalam menyelesaikan permasalahannya.

Menurut pendapat peneliti Kasus yang terjadi di kalangan siswa SMP akan memberi dampak pada kehidupan anak dan perkembangan karakternya. Anak anak yang mengalami bullying dapat membawa luka batin atau trauma hal ini akan membuat anak memiliki kepercayaan diri yang bisa dikatakan rendah. Anak usia remaja (SMP) belum dapat menyelesaikan sendiri masalahnya yang berkaitan dengan gangguan dari teman lainnya. Karena itu sangat diperlukan adanya dukungan orang tua untuk mengarahkan serta menguatkan mental anak sehingga dalam kasus bullying dapat membantu anak lebih percayadiri untuk memilih strategi koping dan dapat meminimalkan dampak negatif dari bullying mengubah menjadi stresor yang positif.

\section{Simpulan}

1. Distribusi responden pada dukungan cukup sebanyak $27(36,5 \%)$

2. Distribusi responden pada startegi coping cukup sebanyak $32(43,2 \%)$

3. Ada hubungan dukungan orang tua dengan strategi coping remaja menghadapibullying di malang

\section{Daftar Pustaka}

Aini, S. Q. (2016) 'Fenomena kekerasan di sekolah (school bullying) pada remaja kabupaten pati', Jurnal Litbang, 12,51-60.

Amini, Y. S. J. (2008) Bullying: Mengatasi kekerasan di sekolah dan lingkungan. Semarang: PT.Grasindo.

Annisya (2020) 'Hubungan Antara Regulasi Emosi Dan Coping Stress Dengan Perilaku Asertif Penggemar Korean-Pop Dalam Menghadapi Cyberbulying', Journals Upi-Yai. Available at: https://journals.upiyai.ac.id/Index.Php/IkraithHumaniora/Article/View/566/419.

Arikunto (2014) Prosedur Penelitian Suatu Pendekatan Praktis. Jakarta: Rineka Cipta. Astuti (2017) Meredam Bullying. Jakarta: Grasindo.

Budhi, S. (2016) Kill Bullying: Hentikan Kekerasan disekolah. Available at: https://osf.io/kcbwq/.

Friedman (2018) Keperawatan Keluarga. Yogyakarta: Gosyen Publishing. Hidayah, F.N. Jainuri (2019) 'skala pengukuran', STKIP YPM. Available at:

https://www.slideshare.net/jenkelana/skalapengukuran-138019935.

KPAI (2020) 'Sejumlah kasus bullying 
sudah warnai catatan masalahb anak di awal 2020,begini kata

komisioner KPAI'

Available at:

https://www.kpai.go.id/berita/sejumlahkasus-bullying-sudah-warnai-catatan masalah-anak-di-awal-2020-beginikata-komisioner-kpai).

Kumala (2020) 'dampak cyberbullying pada remaja di media sosial', Jurnal Alauddin Scintific. ble Availa at:

Masthuroh, I. (2018) Metodologi Penelitian Kesehatan. Jakarta: Kementrian Kesehatan RI. Notoatmodjo (2014) Metodologi Penelitian Kesehatan, PT. Rineka Cipta. Jakarta.

Nursalam (2013) Metodologi Penelitian Ilmu Keperawatan. Jakarta: Salemba Medika.

Nursalam (2016) Metodologi Penelitian Ilmu Keperawatan. Empat. Edited by P. P. Lestari.

Jakarta Selatan: Salemba Medika.

Nwokolo C dan Efobi A (2014) 'Relationship Between Parenting Syles And Tendency To Bullying Behavior Among Adolescents', Education And Human Development.

Putro, K. Z. (2017) 'Memahami Ciri dan Tugas Perkembangan Masa Remaja. Aplikasia' Jurnal Aplikasi Ilmu-ilmu Agama, Vol. 17, N.

Rahayu (2017) Kado SetahunKepemimpinanPenanganan Bullying Berbasis Konseling Online. Semarang: RDRM.

Sarwono, S. W. (2011) Teori-teori Psikologi Sosial. Jakarta: CV. Rajawali.

Siyoto, S. (2015) Dasar Metodologi Penelitian. Edited by Ayup. Yogyakarta:
Literasi Media. Sugiono (2016) Metode Penelitian Kuantitatif Kualitatif dan $R \& D$. Bandung: Alfabeta.

utomo (2016) 'Strategi Copingkorban Bullyingverbal Pada Siswa Kelas Xi Di Sma Negeri 11 Yogyakarta', E-Journal Bimbingan dan Konseling.

Vina Fadhrotul Mukaromah (2020) 'Kasus Bullying Siswa SMP di Malang, KPAI: Sekolah Diduga Tak Miliki Sistem Pengaduan', kompas. Available at: https://www.kompas.com/tren/read/202

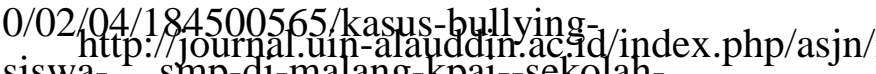
siswa- smp-d1-malang-kpa1--sekolahdiduga-tak-miliki-sistem? page=all.

Yusuf (2012) 'Perilaku bullying: asesmen multidimensi dan intervensi sosial', Psikologi, 11.

Yuyun (2011) Masalah Kesehatan Mental Remaja Di Era Globalisasi. bandung: tidak diterbitkan.

Zainal (2011) 'Pengaruh pelatihan resiliensi terhadap perilaku asertif pada remaja', Jurnal Psikologi, Vol.4No. 2. 